\title{
Using of Pumpkin (Cucurbita moschata) in Making Healthy Functional Ice Milk
}

\author{
Amira M. El-Kholy and F. M. Abbas \\ Dairy Department, Faculty of Agriculture, Suez Canal University, Ismailia 41522, Egypt
}

Received: $15 / 3 / 2015$

\begin{abstract}
Reduced fat and fat free pumpkin ice milk were prepared by replacing fat at ratios of zero, 20, 40, 60, 80 and $100 \%$ with pumpkin puree. Ice milk (52- 60\% overrun) was produced using conventional techniques. The effect of pumpkin puree replacements on the specific gravity, weight per gallon, freezing point, apparent viscosity and some rheological parameters (at different aging time) were evaluated. Also, the sensory evaluation of pumpkin ice milk of different formulas was assessed. Increasing the proportion of pumpkin replacement increased the specific gravity and weight per gallon of the mixes comparing with control. Freezing point gradually decreased as the amount of Cucurbita moschata increased. Mixes apparent viscosity increased by increasing pumpkin ratios and with increasing aging time. Rheological parameters; plastic viscosity and consistency index had the same trend. Products made with replacement of fat at $80 \%$ and $100 \%$ pumpkin melted more slowly and were judged to have slight creamy flavour and formed a gel matrix compared with other treatments while the overrun decreased in a parallel to the replacing ratio of fat with pumpkin up to $60 \%$ then increased. Calculated fibre content $(\mathrm{g} / 100 \mathrm{~g})$ percentage increased as the amount of pumpkin increased. Sensory evaluation revealed that ice milk containing pumpkin (Cucurbita moschata) at levels $80 \%$ and $100 \%$ were given the highest scores compared to the other treatments as it acquired acceptable flavour, creamy texture. This study recommended that replacing fat content with pumpkin up to $80 \%$ and $100 \%$ gave ice milk of good quality accompany with retaining fat - like mouthfeel, and healthy product.
\end{abstract}

Keywords: low calorie ice milk, pumpkin ice milk, functional ice milk, Cucurbita moschata

\section{INTRODUCTION}

Ice cream and frozen desserts are mainly valued for their pleasant flavour, cooling effects and refreshing tastes (Barot Amit et al., 2014). The awareness of consumers for healthier and functional food has led to introduce ice cream manufacture in certain materials with nutritional and physiological properties such as probiotics (Akin et al., 2007), dietary fibers (Soukoulis et al., 2009), alternative sweeteners (Soukoulis and Tzia, 2010), natural antioxidants (Hwang et al., 2009) and low glycemic index sweetners (Whelan et al., 2008). Ice cream may also contain other food products such as fruit, which enhances its nutritive value (Temiz and Yesilsu, 2010). Therefore the use of natural additives to ice cream has an important role (Del Giovine and Piccioli, 2003).

Pumpkin (Cucurbita moschata) consider a good source of both carotenes and dietary fibers. It is rich in beta and alpha carotenes in addition to lutein (Rodriguez-Amaya, 1999). Beta carotene is one of several provitamin A compounds (Foster, 2004) and it is one of an important natural antioxidant. Pumpkin also had role in reducing the risk of developing certain types of cancer (Rodriguez-Amaya, 2003). Several advantages of using fruit fibres in ice cream production are: improvement in body due to the fibrous framework and melting properties, reduction of cold impression and enhancing of mixed viscosities like allowing freezing at higher overrun, causing no negative effect on the ice crystal sizes, and leading to a more homogenous air bubble formation (Anonymous, 2000). Foods rich in dietary fibers (DF) constitute are important sector of the functional foods due to the several health benefits as anti cancer and anti - Oxidants and for lowering blood cholesterol (Arvantoyannis and Houwelingen, 2005). The recommended dietary fiber intakes (DFI) for adults were set to $38 \mathrm{~g}$ for men and $25 \mathrm{~g}$ for women per day (Trumbo et al., 2002).
The objective of this study was to investigate the possibilities of utilizing pumpkin which is characterized by its high nutritional value and healthy foods as a fat replacer in the manufacture of healthy and functional ice milk to replace fat partially or completely and investigate its effect on some physical, rheological and sensory properties of the resultant product.

\section{MATERIALS AND METHODS}

\section{Materials:}

Fresh buffalo's milk (9\% SNF and 6\% fat) was obtained from a private farm in Ismailia Governorate, and was separated to cream (50\% fat) and skim milk which were used in ice milk making. Skim milk powder (Grade A- low heat - spray process-pasteurized) manufactured by Westfarm Foods (96\% total solids), U.S.A.. Gelatin powder was obtained from Adwic (El Nasr Pharmaceutical chemicals). Sugar and Pumpkin (Cucurbita moschata) were purchased from local market.

\section{Experimental procedures:}

\section{Preparation of pumpkin puree:}

Pumpkin fruits (Cucurbita moschata) were washed and peeled, sliced into small pieces (after removing the funicular part and spongy portion containing seed), cooked for $25 \mathrm{~min}$, then cooled to room temperature. Cooked pumpkin was mixed well in a laboratory type blender (Moulinex blender, France) and stored at $-18^{\circ} \mathrm{C}$ until used. The cooked pumpkin had the values of $88.48,1.17,7.48,0.87$ and $1.50 \%$ for moisture, protein, carbohydrate, ash and fiber, respectively.

\section{Preparation of pumpkin ice milk:}

The control mix formula (T1) was standardized to give $5 \%$ fat, $12.5 \%$ milk solids not fat, $15 \%$ sugar and $0.5 \%$ gelatin. Table (1) shows the selected compositions 
of pumpkin ice milk mix formulas and indicated that fat was replaced by pumpkin fruit at levels zero, 20, 40, 60, 80 and $100 \%$. Table (2) shows the formulas of different ingredients for making low and fat free pumpkin ice milk. Ingredients were mixed together, heated at $70^{\circ} \mathrm{C}$ for30 min., cooled to $4^{\circ} \mathrm{C}$ and aged at that temperature overnight prior to freezing. The mixtures $(2 \mathrm{Kg}$ mix for each treatment) were frozen in an ice cream freezing machine (Taylor-mate Model 156, Italy). The resultant ice milk was packaged in cups $(100 \mathrm{ml})$, and put in deep freezer at $-18^{\circ} \mathrm{C}$ for hardening according to Marshall and Arbuckle (1996) for $24 \mathrm{hr}$ before analysis. The whole experiment was carried out in triplicates.

\section{Methods of analysis:}

Moisture, crude fiber, protein and ash content of pumpkin puree were determined according to A.O.A.C. (1990). The ice milk mix was analyzed for titratable acidity according to Ritchardson (1986), pH using digital $\mathrm{pH}$ meter, Jenway $\mathrm{pH}$ meter, Jenway Limited, England), Specific gravity (Winton, 1958), weight per gallon (Burke, 1947), freezing point (FAO Laboratory Manual, 1977), viscosity and rheological parameters were carried out using a Brookfield Digital Rheometer model DV-III+ (Brookfield Engineering Laboratories, Inc., MA, USA), equipped with a $\mathrm{SC}_{4}-21$ spindle. Apparent viscosity was measured at $100 \mathrm{rpm}$. Measurements were made at temperature of $10^{\circ} \mathrm{C}$ in shear rate ranging from 9.3 to $93.0 \mathrm{~S}^{-1}$. All rheological properties were performed in duplicates.

The overrun of resultant ice milk was determined according to (Marshall and Arbuckle, 1996), melting resistant (Tharp et al., 1997), specific gravity (Winton, 1958) and weight per gallon (Burke, 1947).

\section{Sensory evaluation:}

The sensory evaluation for resultant ice milk were carried out by 9 staff members of the Dairy Department, for flavour (45 points), body \&texture (30 points), and appearance $\&$ colour ( 25 points).

\section{Statistical analysis:}

All obtained data were subjected to the statistical analysis and analysis of variance by the procedure of general linear model using CoStat (1998) under windows software version 6.311 and least significant difference (LSD) at $(\mathrm{p}<0.05)$.

Table (1): Selected composition of pumpkin ice milk mix formulas.

\begin{tabular}{lcccccc}
\hline & \multicolumn{7}{c}{$\begin{array}{c}\text { Formula No. } \\
\text { \%o }\end{array}$} \\
\cline { 2 - 7 } & T1 & T2 & T3 & T4 & T5 & T6 \\
\hline Fat & 5 & 4 & 3 & 2 & 1 & 0 \\
Solids not fat & 12.5 & 12.5 & 12.5 & 12.5 & 12.5 & 12.5 \\
Sugar & 15 & 15 & 15 & 15 & 15 & 15 \\
Stabilizer & 0.5 & 0.5 & 0.5 & 0.5 & 0.5 & 0.5 \\
Pumpkin & 0 & 1 & 2 & 3 & 4 & 5 \\
puree & 33 & 33 & 33 & 33 & 33 & 33 \\
Total solids & & & &
\end{tabular}

Table (2): Formulations of pumpkin ice milk mixes.

\begin{tabular}{|c|c|c|c|c|c|c|}
\hline \multirow[t]{2}{*}{ Ingredients } & \multicolumn{6}{|c|}{$\begin{array}{c}\text { Formula No. } \\
\text { g/kg } \\
\end{array}$} \\
\hline & T1 & T2 & T3 & $\mathrm{T4}$ & T5 & T6 \\
\hline Cream (50\% fat) & 100 & 80 & 60 & 40 & 20 & 0 \\
\hline $\begin{array}{l}\text { Buffalo's skim milk } \\
\text { (9\% SNF) }\end{array}$ & 683.6 & 608.8 & 534.1 & 459.3 & 384.6 & 309.9 \\
\hline $\begin{array}{l}\text { Skim milk powder } \\
(96 \% \text { SNF) }\end{array}$ & 61.4 & 69.4 & 77.3 & 85.25 & 93.2 & 101.1 \\
\hline Sugar & 150 & 150 & 150 & 150 & 150 & 150 \\
\hline Gelatin & 5 & 5 & 5 & 5 & 5 & 5 \\
\hline $\begin{array}{l}\text { Pumpkin puree } \\
\text { (11.52\% TS) }\end{array}$ & - & 86.8 & 173.6 & 260.4 & 347.2 & 434.4 \\
\hline
\end{tabular}

\section{RESULTS AND DISCUSSION}

\section{Mix Properties:}

Table (3) showed that, replacing fat by pumpkin puree (Cucurbita moschata) increased the specific gravity and weight per gallon significantly $(p<0.05)$ of mixes, which was proportional to the rate of substitution. The same trend was found for titratable acidity but non significantly $(\mathrm{p}>0.05)$. Acidity increased slightly as percentage of pumpkin increased. On the other hand, $\mathrm{pH}$ values for (T5 and T6) were decreased significantly $(\mathrm{p}<0.05)$ as compared to control ice milk. The freezing point of the mix was lowered $(p<0.05)$ with the increase in the added pumpkin puree and significantly $(p<0.05)$ different among all treatments. These present results are in line with the finding of Ohmes et al. (1998) and El-Kholy (2005), they stated that, when fat is removed from ice cream and is 
replaced with non fat milk solids or other dissolved substances the freezing point is lowered. As it is seen in Table (3), the calculated fibre percentage of pumpkin ice milk ranged from 0.13 to $0.65 \mathrm{~g} / 100 \mathrm{~g}$. Fibre percentage increased significantly $(\mathrm{p}<0.05)$ as the amount of pumpkin increased. The rheological parameters (apparent viscosity, plastic viscosity and consistency index) of ice milk mix during aging at $5^{\circ} \mathrm{C}$ for $24 \mathrm{~h}$ are presented in (Table 4). Apparent viscosity of ice milk mixes and other rheological properties increased pronouncedly $(p<0.05)$ by replacing fat with pumpkin either when fresh or after aging compared to the control. There was a positive $(\mathrm{p}<0.05)$ correlation between viscosity and the rate of replacement Table (4). This may be due to the higher fibre contents of pumpkin which was responsible for gel forming viscous, as well as particle size and high water holding capacity of fibre (Vani and Zayas, 1995 and Hassan, 2005).

Table (3): Effect of Cucurbita moschata as a fat replacer on some properties of reduced fat and fat free pumpkin ice milk mixes.

\begin{tabular}{lcccccc}
\hline \multirow{2}{*}{ Properties } & \multicolumn{5}{c}{ Formula No. ${ }^{*}$} \\
\cline { 2 - 6 } & T1 & T2 & T3 & T4 & T5 & T6 \\
\hline Specific gravity $\left(\mathbf{g m} / \mathbf{c m}^{3}\right)$ & $1.1100^{\mathrm{e}}$ & $1.1154^{\mathrm{de}}$ & $1.1209^{\mathrm{cd}}$ & $1.1265^{\mathrm{bc}}$ & $1.1321^{\mathrm{ab}}$ & $1.1379^{\mathrm{a}}$ \\
Weight/gallon $(\mathbf{K g})$ & $5.046^{\mathrm{f}}$ & $5.0707^{\mathrm{e}}$ & $5.0957^{\mathrm{d}}$ & $5.1211^{\mathrm{c}}$ & $5.1466^{\mathrm{b}}$ & $5.1730^{\mathrm{a}}$ \\
Acidity (\%) & $0.22^{\mathrm{a}}$ & $.022^{\mathrm{a}}$ & $0.22^{\mathrm{a}}$ & $0.23^{\mathrm{a}}$ & $0.24^{\mathrm{a}}$ & $0.24^{\mathrm{a}}$ \\
pH value & $6.35^{\mathrm{a}}$ & $6.35^{\mathrm{a}}$ & $6.35^{\mathrm{a}}$ & $6.33^{\mathrm{ab}}$ & $6.31^{\mathrm{b}}$ & $6.31^{\mathrm{b}}$ \\
Freezing point $\left({ }^{\circ} \mathbf{C}\right)$ & $-2.44^{\mathrm{e}}$ & $-2.45^{\mathrm{e}}$ & $-2.53^{\mathrm{d}}$ & $-2.59^{\mathrm{c}}$ & $-2.64^{\mathrm{b}}$ & $-2.68^{\mathrm{a}}$ \\
Fiber \% & $0^{\mathrm{f}}$ & $0.13^{\mathrm{e}}$ & $0.26^{\mathrm{d}}$ & $0.39^{\mathrm{c}}$ & $0.52^{\mathrm{b}}$ & $0.65^{\mathrm{a}}$ \\
\hline
\end{tabular}

*T2, T3, T4, T5 and T6 different mixes containing 1, 2, 3, 4 and $5 \%$ pumpkin puree respectively.

$\mathrm{a}, \mathrm{b}, \mathrm{c}, \mathrm{d}, \mathrm{e} \& \mathrm{f}$ : means with the same letter among the treatments are not significantly different $(\mathrm{p}<0.05)$.

Table (4): Rheological parameters of reduced fat and fat free mixes of pumpkin ice milk during different aging period at $5^{\circ} \mathrm{C}$.

\begin{tabular}{|c|c|c|c|c|c|c|c|}
\hline \multirow{2}{*}{ Aging Time } & \multicolumn{6}{|c|}{ Formula No. ${ }^{*}$} & \multirow{2}{*}{ Mean $^{* *}$} \\
\hline & T1 & $\mathbf{T}_{2}$ & $\mathbf{T}_{3}$ & $\mathbf{T}_{4}$ & $\mathbf{T}_{5}$ & $\mathbf{T}_{6}$ & \\
\hline \multicolumn{8}{|c|}{ Apparent Viscosity (m Pas) } \\
\hline 0 hour & 12 & 37 & 46 & 84 & 153 & 386 & $119.66^{\mathrm{d}}$ \\
\hline 4 hours & 18 & 41 & 57 & 102 & 179 & 473 & $145.00^{c}$ \\
\hline 8 hours & 34 & 91 & 111 & 233 & 349 & 567 & $230.83^{b}$ \\
\hline 24 hours & 119 & 216 & 278 & 465 & 558 & 797 & $405.50^{\mathrm{a}}$ \\
\hline Mean $^{* *}$ & $45.75^{\mathrm{F}}$ & $96.25^{\mathrm{E}}$ & $123^{\mathrm{D}}$ & $221^{\mathrm{C}}$ & $309.75^{\mathrm{B}}$ & $555.75^{\mathrm{A}}$ & \\
\hline \multicolumn{8}{|c|}{ Plastic viscosity (m Pas) } \\
\hline O hour & 11.5 & 24.1 & 38.3 & 71.3 & 129.8 & 285.8 & $93.46^{\mathrm{d}}$ \\
\hline 4 hours & 14.6 & 35.5 & 49.5 & 71.4 & 150.1 & 344.1 & $110.86^{\mathrm{c}}$ \\
\hline 8 hours & 27.6 & 68.5 & 90.4 & 182.6 & 269.0 & 395.5 & $172.26^{\mathrm{b}}$ \\
\hline 24 hours & 85.3 & 158.4 & 210.2 & 329.3 & 391.8 & 398.7 & $262.28^{\mathrm{a}}$ \\
\hline Mean $^{* *}$ & $34.75^{\mathrm{F}}$ & $71.62^{\mathrm{E}}$ & $97.1^{\mathrm{D}}$ & $163.65^{\mathrm{C}}$ & $235.17^{\mathrm{B}}$ & $356.025^{\mathrm{A}}$ & \\
\hline \multicolumn{8}{|c|}{ Consistency index (m Pas) } \\
\hline (0 hour & 0.90 & 8.60 & 9.97 & 21.8 & 29.1 & 123.4 & $32.29^{\mathrm{d}}$ \\
\hline 4 hours & 3.48 & 14.1 & 14.6 & 62.1 & 88.3 & 165.5 & $58.01^{\mathrm{c}}$ \\
\hline 8hours & 7.37 & 46.6 & 48.1 & 62.1 & 94.4 & 231.4 & $81.66^{\mathrm{b}}$ \\
\hline 24 hours & 49.9 & 85.1 & 106.6 & 228.4 & 270.3 & 620.0 & $226.71^{\mathrm{a}}$ \\
\hline Mean ${ }^{* *}$ & $15.41^{\mathrm{F}}$ & $38.6^{\mathrm{E}}$ & $44.81^{\mathrm{D}}$ & $93.6^{\mathrm{C}}$ & $120.52^{\mathrm{B}}$ & $285.075^{\mathrm{A}}$ & \\
\hline
\end{tabular}

${ }^{*} \mathrm{~T} 2, \mathrm{~T} 3, \mathrm{~T} 4, \mathrm{~T} 5$ and $\mathrm{T} 6$ different mixes containing 1, 2, 3, 4 and 5\% pumpkin puree respectively.

**a $\mathrm{b}, \mathrm{c} \& \mathrm{~d}$ and $\mathrm{A}, \mathrm{B}, \mathrm{C}, \mathrm{D}, \mathrm{E} \& \mathrm{~F}$ : means with the same letter among the treatments and aging period respectively are not significantly different $(\mathrm{p}<0.05)$. 


\section{Ice milk properties:}

The properties of the resultant ice milk from different treatments are illustrated in Table (5). The specific gravity and weight per gallon were higher $(\mathrm{p}<0.05)$ for ice milk treatments (T3 and T4) comparing with control and other treatments, while treatment (T6) had specific gravity and weight per gallon comparable to control ice milk. The level of pumpkin puree in mixes affected $(p<0.05)$ the overrun values. The overrun decreased as substitution of fat increased significantly $(\mathrm{p}<0.05)$ up to $60 \%$ pumpkin compared with control ice milk, then increased pronouncedly $(\mathrm{p}<0.05)$ and reached 55.16 and $55.99 \%$ for treatments T5 and T6 respectively. This increment in the overrun which was observed by increasing the replacement ratios of fat at $80 \%$ and $100 \%$ pumpkin might be due to the better functional properties (whipping and foam ability). It was clearly indicated that as the specific gravity and weight per gallon decreased, the overrun increased. Mahran et al. (1984) stated that the specific gravity of ice milk is inversely proportional to changes occurring in the overrun.
As it is seen in Table (6), the increase of melting resistance of ice milk was proportional $(\mathrm{p}<0.05)$ to the amount of pumpkin (Cucurbita moschata) used. Melting resistance of ice milk was expressed as the loss in weight percent of the initial weight of the tested formula during $60 \mathrm{~min}$ (Table 6). The control ice milk and ice milk with $20 \%$ of fat replacement showed lower $(p<0.05)$ melting resistance than the rest of ice milk treatments made with replacement of fat. It was found that the melting resistance was related to viscosity and freezing point of the mix. These results are in accordance with those of Arbuckle (1986), Salem et al. (2003), Salama and Azzam (2003), El-Kholy (2005) and Abbas (2006). This may be due to their lower content of water holding constituents (Hassan, 2005). On the other hand, the initiation of fluid release was slower $(p<0.05)$ for treatments $\mathrm{T} 6, \mathrm{~T} 5, \mathrm{~T} 4$, and $\mathrm{T} 3$ respectively. This might be due to its higher emulsion stability. Generally, as the mix viscosity increased, the resistance of ice milk to melting increases (Arbucle, 1986; Salem et al., 2003).

Table (5): Effect of Cucurbita moschata as a fat replacer on some properties of reduced and fat free pumpkin ice milk.

\begin{tabular}{|c|c|c|c|c|c|c|}
\hline \multirow{2}{*}{ Properties } & \multicolumn{6}{|c|}{ Formula No." } \\
\hline & T1 & $\mathbf{T 2}$ & T3 & T4 & T5 & T6 \\
\hline $\begin{array}{l}\text { Specific } \\
\left(\mathrm{g} / \mathrm{cm}^{3}\right)\end{array}$ & $0.729^{d}$ & $0.738^{\mathrm{c}}$ & $0.744^{\mathrm{b}}$ & $0.749^{\mathrm{a}}$ & $0.730^{\mathrm{d}}$ & $0.729^{d}$ \\
\hline $\begin{array}{l}\text { Weight/gallon } \\
(\mathrm{Kg})\end{array}$ & $3.314^{\mathrm{e}}$ & $3.355^{\mathrm{c}}$ & $3.382^{\mathrm{b}}$ & $3.405^{\mathrm{a}}$ & $3.318^{\mathrm{d}}$ & $3.314^{\mathrm{e}}$ \\
\hline Overrun (\%) & $52.21^{\mathrm{c}}$ & $51.10^{\mathrm{d}}$ & $50.60^{\mathrm{e}}$ & $50.30^{\mathrm{f}}$ & $55.16^{\mathrm{b}}$ & $55.99^{\mathrm{a}}$ \\
\hline
\end{tabular}

"T2, T3, T4, T5 and T6 different mixes containing 1, 2, 3, 4 and $5 \%$ pumpkin puree respectively.

$\mathrm{a}, \mathrm{b}, \mathrm{c}, \mathrm{d}, \mathrm{e} \& \mathrm{f}$ : means with the same letter among the treatments are not significantly different $(\mathrm{p}<0.05)$.

Table (6): Effect of Cucurbita moschata as a fat replacer on melting resistance (loss \%) of ice milk within 60 min.

\begin{tabular}{|c|c|c|c|c|c|}
\hline \multirow[t]{2}{*}{ Treatments* } & \multicolumn{4}{|c|}{ Melting resistance (loss \%) after } & \multirow{2}{*}{ Mean $^{* *}$} \\
\hline & $15 \mathrm{~min}$ & $30 \mathrm{~min}$ & $45 \mathrm{~min}$ & $60 \mathrm{~min}$ & \\
\hline T1 & 11.20 & 44 & 93 & 96.40 & $61.15^{\mathrm{A}}$ \\
\hline $\mathbf{T} 2$ & 9.60 & 38 & 79.2 & 96.20 & $55.75^{\mathrm{B}}$ \\
\hline T3 & 8.30 & 36.75 & 68.70 & 89.90 & $50.91^{\mathrm{C}}$ \\
\hline T4 & 5.80 & 36.64 & 68.66 & 89.69 & $50.19^{\mathrm{D}}$ \\
\hline T5 & 0.40 & 35.54 & 66.70 & 89.50 & $48.03^{\mathrm{E}}$ \\
\hline T6 & 0.30 & 30.77 & 58.20 & 79.46 & $42.18^{\mathrm{F}}$ \\
\hline Mean $^{* *}$ & $5.93^{\mathrm{d}}$ & $36.95^{\mathrm{c}}$ & $72.41^{\mathrm{b}}$ & $90.19^{\mathrm{a}}$ & \\
\hline
\end{tabular}

"T2, T3, T4, T5 and T6 different mixes containing 1, 2, 3, 4 and $5 \%$ pumpkin puree respectively.

**a, b, c \& d and A, B, C, D, E \& F: means with the same letter among the treatments and melting down duration respectively are not significantly different $(\mathrm{p}<0.05)$.

\section{Sensory evaluation:}

Table (7) represents the sensory evaluation of final product. The results obtained revealed that the reduction of fat up to $5 \%$ (100\% of fat replacement) with pumpkin puree improved significantly $(\mathrm{p}<0.05)$ the body \& texture as compared to control and treatment $2(20 \%$ pumpkin puree). Bahr (1996) stated that fiber ingredients improving texture, appearance, moisture control and shelf life in products. Controlled water absorption, creates altered or finer-sized particles for better mouthfeel. Fibers also, control the water migration in frozen products that was promoted by 
freezing and thawing cycles. Increased pumpkin up to $60 \%, 80 \%$ and $100 \%$ replacement of fat, the scoring of flavour, appearance \& colour and the overall liking scores were increased. However, differences in flavour scores of ice milk from different treatments were found not significant $(p<0.05)$. Ice milk with pumpkin was characterized by a yellow colour due its carotein content. This colour was accepted by the panelists. No significant $(\mathrm{p}>0.05)$ differences were found in scores for colour and appearance between different treatments.

The foregoing results indicated that the importance of using pumpkin fruit (Cucurbita moschata) in ice milk making as a fat replacer not only for improving various quality characteristics and physical properties, but also for healthy reasons. It could be concluded that formulas
(T5 \& T6) containing $80 \%$ and $100 \%$ pumpkin replacement of fat are recommended for the manufacture of functional pumpkin ice milk with high quality and considered a good source of dietary fibers $(0.52-0.65 \%)$ as compared with 20,40 and $60 \%$ replacement $(0.13-0.39 \%)$

\section{CONCLUSION}

Low fat ice milk with high nutritional value and good physical and organoleptic properties can be successfully prepared by replacing up to $100 \%$ of fat in the mix with pumpkin (Cucurbita moschata). The obtained products can be considered as functional ice milk varieties.

Table (7): Sensory evaluation of reduced fat and fat free pumpkin ice milk.

\begin{tabular}{|c|c|c|c|c|c|c|}
\hline \multirow[t]{2}{*}{ Properties } & \multicolumn{6}{|c|}{ Formula No. } \\
\hline & T1 & $\mathbf{T} 2$ & T3 & T4 & T5 & T6 \\
\hline $\begin{array}{l}\text { Flavour } \\
(45)\end{array}$ & $43^{\mathrm{ab}}$ & $42^{b}$ & $43^{\mathrm{ab}}$ & $44^{\mathrm{a}}$ & $44^{\mathrm{a}}$ & $44^{\mathrm{a}}$ \\
\hline $\begin{array}{l}\text { Body \& texture } \\
\text { (30) }\end{array}$ & $28^{\mathrm{b}}$ & $28^{\mathrm{b}}$ & $29^{\mathrm{ab}}$ & $29^{\mathrm{ab}}$ & $29^{\mathrm{ab}}$ & $30^{\mathrm{a}}$ \\
\hline $\begin{array}{l}\text { Colour \& } \\
\text { appearance }(25)\end{array}$ & $24^{\mathrm{a}}$ & $25^{\mathrm{a}}$ & $24^{\mathrm{a}}$ & $25^{\mathrm{a}}$ & $25^{\mathrm{a}}$ & $25^{\mathrm{a}}$ \\
\hline $\begin{array}{l}\text { Total } \\
(\mathbf{1 0 0})\end{array}$ & $95^{\mathrm{b}}$ & $95^{\mathrm{b}}$ & $96^{\mathrm{ab}}$ & $98^{\mathrm{ab}}$ & $98^{\mathrm{ab}}$ & $99^{\mathrm{a}}$ \\
\hline
\end{tabular}

"T2, T3, T4, T5 and T6 different mixes containing 1, 2, 3, 4 and 5\% pumpkin puree respectively.

a, \& b: means with the same letter among the treatments and are not significantly different $(p<0.05)$.

\section{REFERENCES}

Abbas, F. M. (2006). The use of transglutaminase catalyzed crosslinking in the manufacture of low fat ice cream. Agricultural Research Journal, Suez Canal University, 6: 87-92

Akin, MB, MS Akin and Z. Kimaci (2007). Effects of inulin and sugar levels on the viability of yoghurt and probiotic bacteria and the physical and sensory characteristics in probiotic ice cream. Food Chem., 104: 93-99.

Anonymous (2000). Functional properties of Herbacel A Q plus fruit fibres. In: Proceedings of International Conference on Dietary Fibre 2000, May 13-18, Dublin.

Arbuckle, W. S. (1986). Ice Cream, $4^{\text {th }}$ ed., pp. 381-383. AVI publishing Co., Westport Connecticut, USA.

A.O.A.C. (1990). Official methods of analysis. association of official analytical chemists. In: K. Helrich, ed. $15^{\text {th }}$ edition, Arlington, U.S.A.

Arvantoyannis, R. and Houwelingen, K. (2005). Functional foods: A survey of health claims, and current legislations. Critical Rev. Food Sci. \& Nutr., 45: 385.

Bahr, P. S. (1996). New ways to apply fiber. Food products design, Design Elements, Weeks publishing company.

Barot Amit, M, S. Pinto and H. Modha (2014). Development of technology for manufacture of bottle gourd ice cream. J. Nutr. Food Sci., 4: 316, doi: 10, 4172/2155-9600, 1000316.

Burke, A. D. (1947)."Practical ice cream making". The Olson Publishing Co., Milwaukee, Wis., USA.

CoStat (1998). Users manual for CoStat version 6031. Cohort software, Berkeley; CA.

Del Giovine L. and A. Piccioli (2003). Determination of synthetic dyes in ice-cream by capillary electrophoresis. Food Control, 14: 131-135.

El- Kholy, A. M. (2005). Some physical, rheological and sensory properties of ice milk containing rolled oats. J. Agric. Sci. Mansoura Univ., 30(5): 2639-2650.

FAO LAB (1977). Laboratory Manual. FAO Regional Dairy Development and Training Center for the Near East Laboratory Manual.

Foster, R. J. (2004). Fruits plentiful phyto - chemicals. Food Product Design. September. Functional Foods Annual.

Hassan, Z. M. R. (2005). Potential healthy functional ice cream manufacture with pumpkin fruit (Cucurbita pepo). Annals Agric. Sci., Ain Shams Univ., Cairo, 50:161-168.

Hwang Y. J., Y. S. Shyu and CK Hsu (2009). Grape wine lee improves the rheological and adds antioxidants properties to ice cream. LWT Food Sci. and Technol., 42: 312-318.

Mahran, G. A., M. A. El-Ghandour, E. H. El-Bagoury and A. F. Sayed (1984). Effect of skim milk 
powder storage on ice cream quality. Egyptian Journal of Dairy Science, 12: 267-273.

Marshall, R. T. and W. S. Arbuckle (1996). Ice Cream. Fifth ed., Chapman and Hall, New York, USA.

Ohmes, R. L., R. T. Marshall and H. Heymann (1998). Sensory and physical properties of ice creams containing milk fat or fat replacers. J. Dairy Science, 81: 1222-1228.

Richardson, H. G. (1986). Standard methods for the examination of dairy products. $15^{\text {th }}$ ed., American Public Health Association, Washington, USA.

Rodriguez-Amaya, D. B. (1999). Latin-American food sources of caretenoids. Archivos-Latino Americans - De Nutrition, 49: 745-845.

Rodriguez-Amaya, D. B. (2003). Enhancing the carotenoids levels of foods through agriculture and food technology. Internet Paper for Food, Nutrition and Health. Food Africa, Internet Forum, 31.

Salama, F. M. M. and M. A. A. Azzam, (2003). The use of wheat germ in the manufacture of ice milk. Egyptian J. Dairy Sci., 31: 389-398.

Salem, A. S., A. M. Abdelsalam and S. El- Shibiny (2003). Preparation of low fat and low sugar functional ice cream varieties. Egyptian J. Dairy Sci., 31: 399-409.

Soukoulis C., D. Lebesi and C. Tzia (2009). Enrichment of ice cream with dietary fibre: effects on rheological properties, ice crystallization and glass transition phenomena. Food Chem., 115: 665-671.
Soukoulis, C. and C. Tzia (2010). Response surface mapping of the sensory characteristics and acceptability of chocolate ice cream containing alternate sweetening agents. J. Sen Stud., 25: 5075.

Temiz, H. and A. F. Yeşilsu (2010). Effect of pekmez addition on the physical, chemical, and sensory properties of ice cream. Czech J. Food Sci., 28: 538-546.

Tharp, B. W., B. Forrest, C. Swan, L. Dunning and M. Hilmore (1997). Basic factors affecting ice cream meltdown. In: Proceedings of the International Symposium of IDF. Athens. Greece. 18-19 de September, pp. 54-64.

Trumbo, P., S. Schlicker, A. Yates and M. Poos (2002). Dietary reference intakes for energy, carbohydrate, fiber, fat, fatty acids, cholesterol, protein and amino acids. Journal of the American Dietetic Association, 102: 1621-1630.

Vani, B. and J. F. Zayas (1995). Wheat germ protein flour solubility and water retention. J. Food Sci., 60: 845-848.

Whelan, A. P., C. Vega, J. P. Kerry and H. D. Goff (2008). Physicochemical and sensory optimization of a low glycemic index ice cream formulation. Int. J. Food Sci. Technol., 43: 1520-1527.

Winton, A. L. (1958). "Analysis of Foods". $3^{\text {rd }}$ printing, John Wiley and Sons Inc., New York. 6 pp.

\section{استخدام القرع العسلي في صناعة مثلوج لبنى صحي}

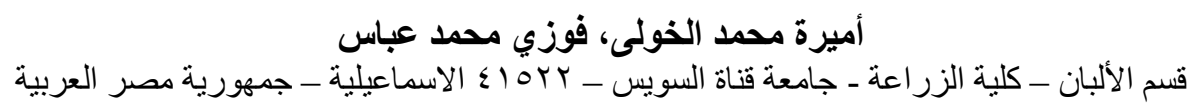

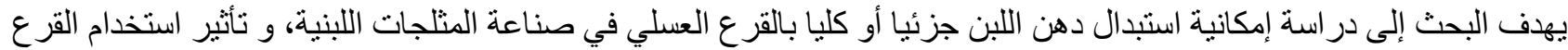
العسلي كبديل للدهن على بعض الخصائص الطبيعية والريولوجية والحسية للمثلوج الناتج. فقد تم استبدال دهن اللبن في مخاليط

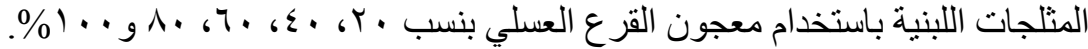

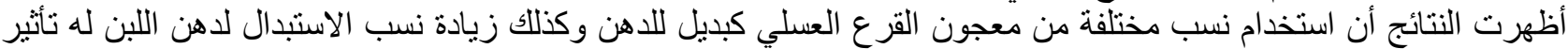

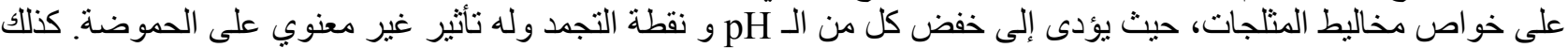

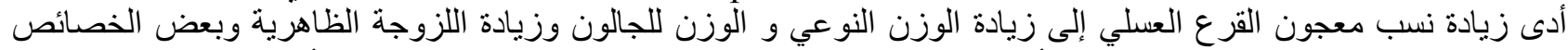

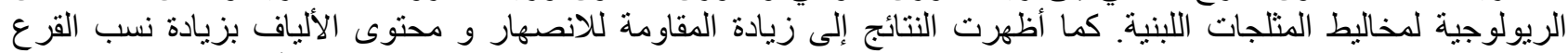

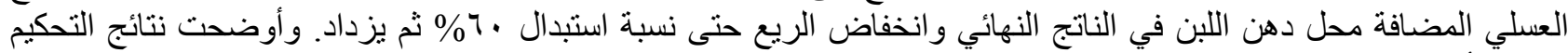

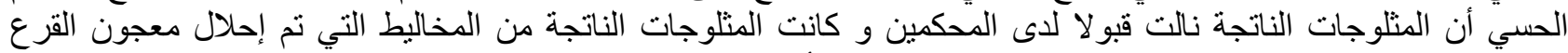

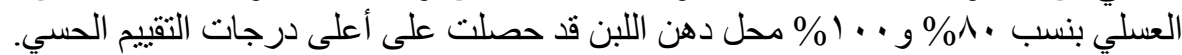

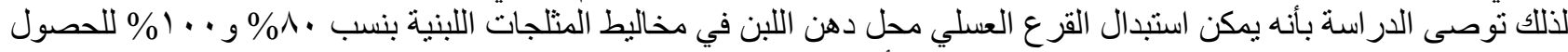
على منتج لبنى جيد من حيث الخو اصن الحسية و غنى بالألياف الغذائية مما يعطى قيمة غذائية و صحية للمنتج. 